\title{
STRATEGI PERUSAHAAN MULTINASIONAL DI ERA GLOBALISASI (STUDI KASUS GLOKALISASI DALAM EKSPANSI "INDOMIE" KE PASAR TIMUR TENGAH DAN AFRIKA)
}

\author{
Hartanto \\ Dosen Tetap Program Studi Hubungan Internasional \\ Fakultas Ilmu Sosial dan Ekonomi \\ Universitas Respati Yogyakarta \\ J1. Laksda Adisucipto Km. 6,3, Depok, Sleman, Yogyakarta 55281 \\ e-mail: tanto0072000@gmail.com
}

\begin{abstract}
ABSTRAK
Globalisasi ditandai dengan berkurangnya batas-batas kegiatan ekonomi antar negara dan wilayah. Kegiatan ekonomi menjadi proses yang terpadu dan melibatkan banyak negara dengan nilai dan budaya yang berbeda. Glokalisasi tampaknya menanggapi hal ini dengan adanya produk global dengan konteks lokal. Indomie sebagai produk industri adalah bukti nyata glokalisasi dalam globalisasi, ketika sesuatu mengglobalisasi maka sesuatu harus dilokalkan. Globalisasi dan glokalisasi seperti dua sisi dalam satu koin tunggal.
\end{abstract}

Kata kunci: Globalisasi, glokalisasi, Indomie

\begin{abstract}
Globalization is characterized by the depletion of the boundaries of economic activities between countries and regions. Economic activities becomes a unified process and involves many countries with different values and cultures. Glocalization appears to respond to this in the presence of a global product with a local context. Indomie as an industrial product is a clear evidence of glocalization in globalization, when something globalize then something should be localized. Globalization and glocalization are like two sides in a single coin.
\end{abstract}

Key words: Globalization, glocalization, Indomie

\section{Pendahuluan}

Globalisasi merupakan sebuah fenomena yang multidimensi, salah satunya adalah dimensi ekonomi. Globalisasi dalam dimensi ekonomi mengakibatkan adanya perubahan dalam struktur dan proses perekonomian dunia mengikuti kemajuan dalam bidang teknologi yang semakin cepat. Perkembangan globalisasi ekonomi telah memunculkan hubungan saling ketergantungan di satu sisi tetapi di sisi lain juga menimbulkan peningkatan persaingan antar negara, dalam konteks perdagangan dan investasi dan kegiatan ekonomi lainnya. Globalisasi ekonomi bercirikan adanya penipisan dan hilangnya batas-batas kegiatan ekonomi antar 
Negara maupun antar wilayah, sehingga kemudian kegiatan ekonomi menjadi sebuah proses yang menyatu dan didalamnya melibatkan banyak negara. Salah satu contoh globalisasi ekonomi adalah Masyarakat Ekonomi ASEAN (MEA), seperti yang saat ini baru saja bergulir. Arus barang serta jasa dan faktor-faktor produksi lintas negara atau regional akan menjadi semakin mudah. Bentuk lain globalisasi ekonomi adalah mudahnya akses untuk melakukan investasi, seperti yang dilakukan oleh PT. Indofood Sukses Makmur dengan membangun pabrik di Afrika dan TimurTengah untuk memasarkan produk unggulannya Indomie.

Globalisasi dalam dimensi ekonomi memasuki pasar dengan cara yang sistematis dengan tahapan pasar domestik, internasional, multinasional, global, dan transnasional melalui produk dan jasa, teknologi, budaya, dan sebagainya. Hal tersebut kemudian dimanfaatkan oleh PT. Indofood sukses makmur untuk melakukan ekspansi usahanya tidak hanya di dalam negeri tetapi juga di luar negeri. Terkait dengan globalisasi ekonomi secara umum dan PT. Indofood Sukses Makmur dengan produk unggulannya Indomie yang sudah beredar di mancanegara, makalah ini berupaya untuk melakukan kajian mengenai Indomie sebagai sebuah produk industri menjadi bagian dari globalisasi ekonomi yang kemudian berdampak juga pada globalisasi sosial budaya, strategi yang digunakan serta kaitan antara keduanya.

\section{Rumusan Masalah}

Menyimak gambaran mengenai globalisasi dalam dimensi ekonomi dan juga sedikit pemaparan mengenai globalisasi dalam dimensi sosial budaya serta fenomena produk PT. Indofood Sukses Makmur yaitu Indomie yang telah merambah ke mancanegara pada bagian pendahuluan, maka rumusan masalah dalam makalah ini adalah:

1) Bagaimana Indomie sebagai sebuah produk industri menjadi bagian dari globalisasi?

2) Mengapa Indomie merespons globalisasi dengan melakukan juga glokalisasi?

3) Bagaimana kaitan antara globalisasi dengan glokalisasi dalam konteks Indomie dan secara umum?

\section{Kerangka Teori}

Untuk menjawab pertanyaan dalam rumusan masalah diatas, maka teori atau konsep yang akan penulis gunakan sebagai alat analisis adalah globalisasi dalam dimensi ekonomi dan sosial budaya, communitarianism serta glokalisasi.

\section{Globalisasi dalam Dimensi Ekonomi dan Sosial Budaya}

Globalisasi merupakan proses meningkatnya keterkaitan antar masyarakat di seluruh dunia sehingga peristiwa yang terjadi di suatu bagian dunia semakin memberi dampak terhadap masyarakat di bagian dunia yang lain (Baylis\&Smith, 2001: 14). Sedangkan menurut Held et al (1999: 16), globalisasi merupakan sebuah atau serangkaian proses yang mewujudkan transformasi dari organisasi spasial hubungan sosial dan transaksi. Dari dua definisi mengenai globalisasi diatas kita dapat memahami bahwa globalisasi merupakan sebuah proses meningkatnya keterkaitan atau hubungan diantara aktor-aktor baik itu Negara maupun non-Negara 
dalam konteks hubungan yang bersifat multidimensi baik itu politik, ekonomi, dan sosial budaya.

Globalisasi dalam dimensi ekonomi (economic globalization) mengacu pada intensifikasi dan peregangan keterkaitan ekonomi di dunia. Arus modal dan teknologi yang sangat besar telah mendorong meningkatnya perdagangan barang dan jasa. Pasar telah menambah jangkauan mereka di seluruh dunia, dalam proses menciptakan hubungan baru antara ekonomi nasional. Perusahaan transnasional yang besar, lembaga ekonomi internasional yang kuat, dan sistem perdagangan regional yang besar telah muncul sebagai pilar tatanan ekonomi global (Steger, 2003: 37). Globalisasi ekonomi juga ditandai dengan semakin meluasnya ekonomi pasar yang dipromosikan oleh lembaga-lembaga internasional seperti International Monetary Fund (IMF) dan Bank Dunia sebagai manifestasi penggerak modernisasi dan pembangunan (Jati, 2013: 254). Globalisasi ekonomi identik dengan neoliberalism. Pelaksanaan ide neoliberalism berlangsung di awal 90-an ketika neoliberalism menerima legitimasi lebih lanjut setelah runtuhnya Uni Soviet. Oleh karena itu, menurut Steger (2003), kita dapat melihat tiga perkembangan yang paling signifikan yang terkait dengan globalisasi ekonomi antara lain: Internalisasi keuangan dan perdagangan, meningkatkan kekuatan perusahaan-perusahaan transnasional dan lembaga ekonomi internasional.

Globalisasi ekonomi ditandai dengan makin menipisnya batas-batas investasi atau pasar secara nasional, regional ataupun internasional. Hai ini disebabkan oleh: (a) komunikasi dan tranportasi yang semakin canggih, (b) lalulintas devisa yang makin bebas, (c) ekonorni negara yang makin terbuka, (d) penggunaan keunggulan komparatif dan keunggulan kompetitif oleh setiap Negara (e) metode produksi dan perakitan dengan organisasi yang makin efisien, (f) semakin pesatnya perkembangan perusahaan multinasional di seluruh dunia (Halwani, 2005: 194).

Salah satu contoh yang disebutkan dalam Steger (2003) adalah kasus peran Nokia dalam ekonomi Finlandia. Setelah menjadi salah satu Trans National Corporations (TNCs) terbesar ketergantungan ekonomi negara menjadi jelas. Perusahaan-perusahaan transnasional telah menjadi inti produktif ekonomi dunia yang mengglobal. Dalam hal energi, mereka menambang, memperbaiki dan mendistribusikan sebagian sumber daya dunia. Mereka memproduksi dan menjual sebagian besar mobil, pesawat terbang, komunikasi satelit, komputer, elektronik, obat-obatan dan bioteknologi. Mereka menanam banyak tanaman utama dalam dunia pertanian, serta memproses dan mendistribusikannya dalam bentuk makanan.

Globalisasi dalam dimensi sosial budaya (Cultural globalization) mengacu pada intensifikasi dan perluasan arus budaya di seluruh dunia. Konsep 'budaya' adalah sangat luas, konsep budaya sering digunakan untuk menggambarkan pengalaman seluruh manusia. Untuk menghindari masalah berikutnya dari generalisasi yang berlebihan, adalah penting untuk membuat perbedaan analitis antara aspek kehidupan sosial. Sebagai contoh, kita mengasosiasikan kata 'ekonomi' dengan produksi, pertukaran, dan konsumsi komoditas. Jika kita membahas 'politik', berarti berhubungan dengan generasi dan distribusi kekuasaan dalam masyarakat. Jika kita berbicara tentang 'budaya', terkait dengan konstruksi simbolik, artikulasi, dan penyebaran makna. Mengingat bahwa bahasa, musik, dan gambar merupakan 
bentuk utama ekspresi simbolik, mereka menganggap istimewa signifikansi di bidang budaya (Steger, 2003: 69).

Pendapat lain menyebutkan bahwa globalisasi dalam dimensi sosial budaya mengacu pada transmisi ide-ide, makna dan nilai-nilai di seluruh dunia dengan cara memperluas dan mengintensifkan hubungan sosial (James, 2006: 20). Proses ini ditandai dengan konsumsi secara umum budaya yang telah menyebar oleh Internet, budaya populer dari media, dan perjalanan internasional serta proses pertukaran komoditas dan kolonisasi yang memiliki sejarah yang lebih panjang membawa makna budaya di seluruh dunia. Sirkulasi budaya memungkinkan individu untuk ikut serta dalam hubungan sosial yang melintasi batas-batas nasional dan regional. Penciptaan dan perluasan hubungan sosial tersebut tidak hanya diamati pada tingkat material. Globalisasi budaya melibatkan pembentukan norma-norma bersama dan pengetahuan dengan identitas budaya individu dan kolektif mereka. Ini membawa peningkatan keterkaitan antara populasi yang berbeda dan budaya (Steger dan James, 2010).

Aspek nyata globalisasi budaya salah satunya adalah difusi masakan/makanan tertentu seperti rantai makanan cepat saji Amerika. Dua rantai makanan cepat saji yang paling sukses adalah gerai makanan dan minuman global, seperti McDonald dan Starbucks. Perusahaan-perusahaan Amerika tersebut seringkali dijadikan contoh globalisasi, McDonald memiliki lebih dari 36.889 gerai (Annual Report McDonald: 2016) dan Starbucks memiliki 18.000 gerai di seluruh dunia, pada tahun 2008 (Steger, 2009: 149), bahkan Big Mac Index merupakan ukuran perbedaan daya beli antara mata uang dunia secara informal.

Dari uraian mengenai globalisasi dalam dimensi ekonomi dan sosial budaya, penulis memiliki pemahaman bahwa globalisasi dalam dimensi ekonomi memungkinkan adanya aliran modal, barang mapun jasa yang lebih bebas. Dimensi ekonomi dalam globalisasi dapat dikaitkan dengan globalisasi dalam dimensi sosial budaya, dengan adanya kebebasan dalam arus modal, barang maupun jasa tentunya mendorong aksesibilitas masyarakat terhadap barang dan jasa dari luar negeri yang kemudian membawa pengaruh pada kehidupan sosial maupun budaya dalam masyarakat lokal.

\section{Komunitarianisme}

Salah satu perkembangan dalam filsafat politik, adalah munculnya komunitarianisme, yang mengutamakan nilai komunitas dan mengkritik individualisme liberalisme. Menurut mereka, otonomi individu yang ditonjolkan liberalisme bersifat atomistik dan transenden. Liberalisme yang mereka kritik terutama adalah liberalisme egalitarian yang dikemukakan oleh Rawls dan Dworkin. Sedangkan fokus dari kritik mereka adalah otonomi individu, netralitas negara dan universalisme (Aida, 2005: 98).

Komunitarianisme mengingatkan kita bahwa individu tidak mampu dan tidak bisa hidup secara penuh di luar masyarakatnya, dan menyoroti konsekuensi antisosial individualisme yang atomistik. Komunitarianisme juga mempertanyakan gagasan liberal dari negara netral. Namun, komunitarianisme mengancam, atau tidak menjamin, hak-hak individu dan kebebasan, dan menimbulkan masalah relativisme moral (Morrice, 2000: 246). 
Ada dua pandangan yang dikemukakan tentang komunitarianisme. Pertama, sebagai pandangan positif, komunitarianisme dinilai sebagai salah satu perspektif dalam filsafat politik yang menekankan nilai etis dan psikologis sosial dari anggotaanggota komunitas. Justifikasi dari pertimbangan etika ditentukan oleh fakta-fakta yang berada dalam konteks pemahaman kultural dan tradisi-tradisi komunitas. Kedua, sebagai pandangan negatif, komunitarianisme dinilai sebagai anti liberalisme. Ia merupakan kritik terhadap nilai-nilai liberalism (Aida, 2005: 99).

Komunitarianisme menekankan ketergantungan dan keterikatan individu pada komunitasnya. Karenanya, liberalism dengan otonomi individunya dinilai menjadikan manusia transenden, terlepas dan terpisah dari keberadaan komunitasnya. Yang termasuk tokoh komunitarianisme antara lain Michael Sandel, Michael Walzer, Alasdair Mac Intyre dan Charles Taylor. Menurut komunitarianisme, individu tertanam atau melekat pada praktek-praktek sosial. Setiap orang tidak selalu dapat mengambil jarak atau melepaskan diri dari berbagai praktek sosial tersebut (Aida, 2005: 99).

Komunitarianisme mendorong orang untuk menerima konsep-konsep kebaikan yang sesuai dengan pandangan hidup masyarakat dan mencegah berbagai konsep tentang kebaikan yang bertentangan dengan pandangan hidup komunitas tersebut. Komunitarianisme menjadikan nilai-nilai komunitas sebagai otoritas horison yang menetapkan tujuan hidup bagi manusia. Ada praktek-praktek komunitas tertentu yang dapat didukung oleh setiap orang sebagai basis dari sebuah politik kebaikan bersama (Aida, 2005: 100).

Konsep individualisme liberalisme bertujuan untuk menjadikan individu sebagai fokus atau subjek perhatian. Individu merupakan aspek pokok yang harus diperhatikan keberadaannya. Meskipun individu-individu membentuk atau berada pada satu komunitas, namun eksistensinya tidak dapat direduksi atau diabaikan demi nilai individu-individu yang lainnya atau nilai komunitas secara keseluruhan. Karenanya, liberalisme sangat menekankan nilai kebebasan yang akan menghasilkan otonomi pada individu. Individu yang otonom akan bertindak dan memilih cara hidup yang baik sesuai dengan keyakinan dalam dirinya, tanpa intervensi dari luar.

Dari uraian mengenai komunitarianisme penulis mendapatkan pemahaman bahwa komunitarianisme merupakan sebuah pandangan yang melihat bahwa ditengah arus globalisasi yang mengedepankan homogenitas, komunitarianisme tetap mempertahankan nilai-nilai lokal dan heterogenitas. Individu tidak akan mampu lepas dari komunitas dan nilai-nilai yang bersumber dari daerah asalnya meskipun terpapar homogenitas globalisasi.

\section{Glokalisasi}

Istilah glokalisasi diartikan secara sederhana adalah campuran antara konten global dengan konten lokal (Robertson, 1995). Menurut Wordspy, glokalisasi berarti "penciptaan produk atau jasa yang ditujukan untuk pasar global, namun disesuaikan dengan budaya lokal (Wilk, 1995: 118)." Glokalisasi adalah penyesuaian produk global dengan karakter pasar masyarakat lokal.

Glokalisasi menjadi strategi yang muncul sebagai kritik terhadap konsep perdagangan bebas neoklasik, yang tidak lagi menspesialisasikan sebuah negara dalam satu produk sesuai dengan potensinya. Karena itu, para produsen 
mengkondisikan sebuah negara (pasar) agar berada dalam satu latar belakang sosial budaya yang sama dengan negara lain (Robertson, 1992). Tujuan utama dari glokalisasi menurut Kotler et al (2009) adalah: (a) konsumen dapat merasakan bahwa suatu produk relevan dan sesuai dengan kebutuhan dan keinginannya, (b) adanya harmoni dan keseimbangan di antara tingkat marketing yang berbeda, (c) produk mendapatkan market share yang lebih besar.

Menurut Robertson (1992), aspek-aspek yang dipandang penting dalam proses glokalisasi, adalah: (a) dunia sedang bekembang menjadi lebih menghormati keanekaragaman. (b) para individu dan semua kelompok yang sifatnya lokal memiliki kekuatan untuk beradaptasi, berinovasi, dan bergerak di dalam sebuah dunia yang mengalami glokalisasi. Teori glokalisasi memandang individu dan kelompok lokal sebagai agen sosial yang penting dan kreatif. (c) semua proses sosial bersifat saling berkaitan dan bergantung satu sama lain. (d) komoditas dan media tidak dipandang secara koersif, tetapi menyediakan materi untuk digunakan dalam ciptaan pribadi atau kelompok di seluruh dunia yang mengalami glokalisasi.

Dari uraian ditas glokalisasi dapat dipahami dari istilah globalisasi yang melibatkan banyak proses, didalamnya terdapat proses pencampuran dan adaptasi dan di antara proses tersebut haruslah konten lokal, dengan kata lain glokalisasi merupakan campuran antara global dan lokal konten, seperti sebuah istilah yang sering kita dengar "Think Globally, act locally".

\section{Kerangka Pemikiran}

Globalisasi memungkinkan sebuah produk untuk melakukan ekspansi pasar pada tataran global dengan semakin terbukanya ekonomi Negara-negara, namun dalam ekspansi tersebut harus memperhatikan nilai-nilai sosial dan budaya lokal, karena menurut komunitarianisme individu tidak bisa lepas dari nilai-nilai sosial dan budaya yang ada dalam komunitasnya, dengan asumsi tersebut sebuah produk harus menyesuaikan karakternya dengan nilai-nilai sosial dan budaya lokal, penyesuaian tersebut dinamakan glokalisasi, seperti juga terjadi pada kasus glokalisasi Indomie dalam makalah ini.

\section{Hipotesis}

Hipotesis atau argumen utama dalam makalah ini adalah:

1) Indomie sebagai sebuah produk industri menjadi bagian dari globalisasi melalui pemasaran global yang dilakukan oleh PT. Indofood Sukses Makmur di Timur Tengah dan Afrika sebagai respons terhadap adanya globalisasi ekonomi.

2) Indomie merespons globalisasi dengan melakukan juga glokalisasi karena Indomie menginginkan konsumen dapat merasakan bahwa Indomie sebagai suatu produk relevan dan sesuai dengan kebutuhan serta keinginannya, Indomie menginginkan adanya harmoni dan keseimbangan di antara tingkat marketing yang berbeda, Indomie mendapatkan market share yang lebih besar.

3) Globalisasi dengan glokalisasi memiliki keterkaitan karena tidak mungkin untuk melakukan homogenisasi produk tanpa memperhatikan dimensi nilainilai sosial dan budaya lokal. 


\section{Bahasan}

\section{Indomie sebagai bagian dari Globalisasi}

Globalisasi tentunya memunculkan realitas ekonomi atau komersial yang baru dengan hilangnya perbedaan preferensi dalam konteks transaksi dalam bidang konsumsi yang disebabkan munculnya standarisasi operasi, pemasaran dan produk (Shafi et al, 2014). Realitas komersial tersebut berdasarkan pada munculnya pasar global untuk produk konsumen terstandarisasi pada skala yang tidak terbayangkan sebelumnya (Levitt, 1983).

Hal tersebut kemudian disikapi oleh perusahaan-perusahaan secara umum dan PT. Indofood Sukses Makmur Tbk khususnya dengan Indomie sebagai salah satu produknya. Menurut Change (1992) perusahaan yang memiliki niat untuk go global atau go internasional dengan melakukan perluasan pasar di tingkat internasional harus melakukan perencanaan yang matang dan eksekusi yang efektif dengan memperhatikan standarisasi dalam hal iklan serta elemen lainnya seperti strategi, eksekusi dan bahasa.

Dalam konteks go internasional, lebih dari 20 tahun PT. Indofood Sukses Makmur Tbk memperkenalkan Indomie, produk mie instant ke pasar internasional. Kini, Indomie bukan hanya dikenal di negara tetangga dekat seperti Singapura, Malaysia, Hong Kong hingga Taiwan. Namun, Indomie sudah terbang jauh ribuan kilometer, menjangkau lebih dari 80 negara, baik di Eropa, Timur Tengah, Afrika hingga Amerika. Di Sudan dan Libanon, Indomie hampir ada di setiap toko retail dan super market. Bahkan, Indofood juga membangun pabrik di sejumlah negara, seperti di Malaysia, Saudi Arabia, Nigeria, Suriah hingga Mesir (Susanto, 2013).

Pada sisi perencanaan dan strategi PT. Indofood Sukses Makmur Tbk memulainya dengan membentuk Direktorat Ekspor dengan tugas fokus mengembangkan ekspor Indomie ke berbagai negara. Tim ini aktif mempelajari semua izin impor di setiap negara. Lantas, menetapkan target negara. Saat itu, sasaran utamanya, negara dengan jumlah tenaga kerja Indonesia paling banyak sehingga Indomie populer di Hong Kong, Taiwan, Arab Saudi dan lainnya. Bahkan, di Arab Saudi konsumen Indomie sudah masuk generasi kedua. Saat pertama kali Indomie masuk pada 1990-an, mereka masih anak-anak, sekarang mereka sudah dewasa dan berkeluarga. Selain TKI, Indomie juga dibawa oleh para pelajar-pelajar Indonesia di luar negeri, sehingga Indomie juga populer di negara-negara seperti Amerika Serikat dan Australia, negara yang menjadi tujuan pelajar Indonesia melanjutkan pendidikannya(Susanto, 2013).

Setelah menetapkan negara tujuan ekspor, Indofood membentuk regional office di masing-masing negara. Bahkan, kami melangkah lebih jauh dengan membangun pabrik di beberapa negara lain yang menjadi target pasar utama Indomie, seperti Nigeria. Dengan pabrik di negara-negara tersebut, Indofood tetap bisa mengekspor produk lainnya, seperti bumbu, saos atau kecapnya. Sebab, bumbubumbu itu hanya bisa dibuat di Indonesia. Perkembangan di pasar ekspor tersebut juga didukung oleh keberadaan toko-toko Indonesia di beberapa negara, seperti di Thailand, Hong Kong, Taiwan hingga Arab Saudi. Bahkan, di Arab Saudi ada 1200 toko yang khusus menjual makanan Indonesia (Susanto, 2013).

Disamping itu PT. Indofood Sukses Makmur Tbk juga melakukan quality control dalam beberapa aspek antara lain: (a) keamanan bagi pembeli. Keamanan 
dari sisi produk dan proses produksi sesuai standar internasional, (b) bahan baku diperoleh dari kebun atau pertanian yang sudah memenuhi standar good coming practice, (c) melakukan sertifikasi ISO 9001: 2000 dan HACCP (Hazard Analysis \& Critical Control Points) sebagai pemenuhan persyaratan standar bagi eksportir untuk masuk negara tertentu sebagai jaminan keamanan, agar retail shop mau menjual kepada konsumen di Negara tersebut (Susanto, 2013).

Dari uraian diatas kita dapat melihat bahwa PT. Indofood Sukses Makmur Tbk dengan Indomie sebagai salah satu produknya jeli melihat peluang di era globalisasi ekonomi dengan melakukan apa yang disebut oleh (Levitt, 1983) bahwa pasar global untuk produk konsumen melakukan standarisasi pada skala yang tidak terbayangkan sebelumnya, dan juga sesuai dengan pernyataan Change (1992) bahwa perusahaan yang memiliki niat untuk go global atau go internasional dengan melakukan perluasan pasar di tingkat internasional harus melakukan perencanaan yang matang dan eksekusi yang efektif dengan memperhatikan standarisasi dalam hal iklan serta elemen lainnya seperti strategi, eksekusi dan bahasa.

Di samping itu Indomie juga memanfaatkan apa yang disebut oleh komunitarian bahwa individu tidak bisa lepas dari nilai sosial dan budaya komunitasnya dalam bentuk memasarkan Indomie melalui TKI, dan dibawa oleh para pelajar-pelajar Indonesia di luar negeri, sehingga Indomie juga populer di negara-negara seperti Amerika Serikat dan Australia, negara yang menjadi tujuan pelajar Indonesia melanjutkan pendidikannya, hal ini merupakan sebuah bukti bahwa Indomie memanfaatkan globalisasi tanpa mengesampingkan nilai-nilai sosial budaya suatu komunitas.

\section{Glokalisasi sebagai Respons Indomie terhadap Globalisasi}

Unsur-unsur sosial budaya harus diperhatikan dalam konteks pemasaran suatu produk secara global. Jika kita kembali melihat pada konsep komunitarianisme di atas, bahwa individu selalu akan terkait dengan nilai sosial budaya dari komunitasnya, maka glokalisasi merupakan sebuah keniscayaan yang harus dilakukan dalam memasarkan suatu produk agar relevan dan sesuai dengan kebutuhan dan keinginan, adanya harmoni dan keseimbangan di antara tingkat marketing yang berbeda, serta mendapatkan market share yang lebih besar.

Glokalikasi dipahami oleh penulis sebagai proses penawaran atau masuknya produk global dengan memperhatikan nilai-nilai sosial budaya lokal yang ada. Dengan demikian, produk global ini tetap memanfaatkan global-brand yang dimilikinya, namun melakukan adaptasi sesuai dengan konteks budaya lokal yang ada. Salah satu contoh glokalisasi Indomie adalah dengan menerapkan rasa lokal pada produknya di Negara tujuan pemasaran. Sebagai contoh Indomie di Nigeria memiliki rasa yang berbeda dengan di Indonesia, Indomie di Nigeria memiliki tiga rasa, yakni: pepper chicken, onion chicken, oriental (Julianto, 2017). Di Afrika khususnya Nigeria misalnya, Indomie begitu kokoh dan sangat populer di kalangan warga negaranya. Terdapat cerita lucu, ada seorang warga Nigeria berkunjung ke Jakarta dan mendapati Indomie di sebuah supermarket. "Lho Indomie kan bikinan asli Nigeria, kok ada di sini," seloroh si warga Nigeria spontan Ini bukti memang Indomie sudah menjadi merek yang dikenal luas di Nigeria (Koran Sindo, 20 Mei 2015). Sedangkan di Arab Saudi Indomie memiliki rasa Vegetable, Green Chili, dan 
Special Chicken (Ramadhana, 2015). Glokalisasi dilakukan dengan melakukan penyesuaian dengan budaya lokal untuk menarik minat konsumen masyarakat lokal sehingga tidak menyadari bahwa produk tersebut merupakan produk asing.

Strategi glokalisasi yang lain adalah dengan membangun pabrik untuk memproduksi Indomie di manca negara. Pabrik Indomie sudah hadir di Nigeria sejak 20 tahun lalu dengan karyawan sekitar 6.000 orang dan menguasai pangsa pasar sampai 70 persen di kawasan Afrika Barat. Dari pabrik di Nigeria ini Indomie diekspor ke berbagai penjuru dunia. Karena melakukan aktivitas pemasaran dan building brand sejak lama, Indomie sangat populer di Nigeria (Koran Sindo, 20 Mei 2015). Pabrik mi instan serupa juga dibangun di Arab Saudi pada 1992 dan sejak saat itu, produk mi instan tersebut pun laku keras dan digemari masyarakat di sana. Dikutip dari website resmi Indomie Arab Saudi, pabrik Indomie yang ada di Arab Saudi total ada tiga. Dua pabrik memproduksi mie yaitu di Jeddah dan Dammam, satu pabrik lagi khusus memproduksi kecap dan sambal. Pabrik di Jeddah hadir lebih dulu, dibangun pada tahun 1992 dan mulai berjalan pada 1994 yang mampu memproduksi sebanyak 2 juta bungkus per hari. Produksi bumbu dan minyak baru berjalan pada Agustus 2005. Sedangkan pabrik di Dammam dibangun pada 2005 dan mulai beroperasi pada 2007 dengan kapasitas produksi yang lebih besar yaitu 4 juta bungkus per hari (Ramadhana, 2015).

Dari uraian diatas kiranya tepat untuk menyebutkan bahwa Indomie juga melakukan glokalisasi dengan tujuan konsumen dapat merasakan bahwa Indomie relevan dan sesuai dengan kebutuhan dan keinginannya. Disamping itu dengan glokalisasi Indome mendapatkan market share yang lebih besar di Negara-negara yang menjadi pasar untuk penjualan, terbukti dengan Indomie punya pabrik besar di Nigeria dengan karyawan sekitar 6.000 orang dan menguasai pangsa pasar sampai 70 persen di kawasan Afrika Barat.

\section{Kaitan Globalisasi dan Glokalisasi dalam Konteks Indomie}

Bersamaan dengan memudarnya negara-bangsa secara bertahap, fenomena globalisasi muncul. Globalisasi harus dipahami sebagai suatu proses, yang melibatkan banyak dimensi baik itu ekonomi, kelembagaan, dan sosial-budaya. Pada saat yang sama, kita harus menggarisbawahi bahwa manifestasi tertentu dari proses global dapat diamati di daerah pada tataran lokal dan dualitas antara global dan lokal merupakan hal yang tidak tepat. Menurut penulis globalisasi dan glokalisasi dibaratkan seperti dua sisi dalam sekeping uang logam. Glokalisasi terdiri dari dua proses: globalisasi dan lokalisasi. Sementara lokalisasi mengacu manusia, subyek individu, organisasi, masyarakat atau daerah, globalisasi mencakup proses mendunianya segala sesuatu. Namun, penyebab proses global dapat selalu ditemukan di pada tataran lokal. Hal tersebut disebabkan oleh adanya pandangan komunitarianisme di mana globalisasi tidak seharusnya melakukan homogenisasi.

Glokalisasi sering diartikan sebagai "think globally act locally, yang dianggap sebagai kemungkinan strategi yang tepat untuk pembangunan berkelanjutan masa depan seluruh dunia. Istilah tersebut mengekspresikan kemampuan manusia untuk mengatasi (setidaknya mental) dalam konteks territorial yang berbeda. Glokalisasi juga cukup sering dianggap sebagai konsep yang sedang diadopsi oleh entitas ekonomi yang besar. Glokalisasi diartikan sebagai penyesuaian produk dan jasa dari sebuah perusahaan dalam rangka memenuhi kepentingan pasar lokal yang berbeda-beda di seluruh dunia. 
Dalam konteks fenomena Indomie sebagai sebuah produk industri kita dapat melihat bahwa memang ada keterkaitan seperti dua sisi mata uang yang berbeda antara globalisasi dan glokalisasi. Di satu sisi Indomie mampu memanfaatkan arus globalisasi dengan melakukan ekspansi pasar ke luar negeri, namun hal tersebut tentunya membawa konsekuensi bahwa dunia memiliki kondisi budaya yang berbeda, dengan melihat hal tersebut kemudian Indomie melakukan penyesuaian dengan konten lokal dari tujuan ekspansi pasarnya. Penyesuaian tersebut adalah dengan melakukan modifikasi rasa dari produk Indomie yang disesuaikan dengan selera lokal dari tujuan ekspornya, seperti juga apa yang dilakukan Mc Donald ketika memasukan nasi pada menunya di pasar Indonesia. Pada akhirnya penulis mendapatkan gambaran dan pemahaman bahwa globalisasi sangat berkaitan dan tidak terpisahkan dengan glokalisasi dalam konteks penyesuaian terhadap nilai lokal sebuah produk industri makanan, hal tersebut menjadikan bukti bahwa pandangan komunitarianisme menunjukan relevansinya bahwa globalisasi tidak bisa melakukan homogenisasi secara menyeluruh.

Secara keseluruhan dari bahasan diatas membuktikan hipotesis makalah ini bahwa Indomie sebagai sebuah produk industri menjadi bagian dari globalisasi melalui pemasaran global yang dilakukan oleh PT. Indofood Sukses Makmur di Timur Tengah dan Afrika sebagai respons terhadap adanya globalisasi ekonomi. Indomie merespons globalisasi dengan melakukan juga glokalisasi karena Indomie menginginkan konsumen dapat merasakan bahwa Indomie sebagai suatu produk relevan dan sesuai dengan kebutuhan serta keinginannya. Indomie menginginkan adanya harmoni dan keseimbangan di antara tingkat marketing yang berbeda, Indomie mendapatkan market share yang lebih besarGlobalisasi dengan glokalisasi memiliki keterkaitan karena tidak mungkin untuk melakukan homogenisasi produk tanpa memperhatikan dimensi nilai-nilai sosial dan budaya lokal.

\section{Simpulan}

Globalisasi membawa konsekuensi pada tumbuhnya peluang untuk melakukan ekspansi pasar yang kemudian berpengaruh juga pada dimensi sosial budaya. Globalisasi yang identik dengan homogenisasi ternyata kurang memperhatikan konteks lokalitas dari masingmasing wilayah. Hal tersebut memunculkan apa yang disebut dengan komunitarianisme dimana komunitarianisme meyakini bahwa individu akan selalu identik dengan nilai-nilai komunitasnya meskipun terpapar oleh globalisasi. Indomie sebagai salah satu produk industri Indonesia penulis kira menyadari sepenuhnya bahwa globalisasi tidak seharusnya mengesampingkan nilai-nilai lokal, terbukti dari proses glokalisasi yang dilakukannya melalui heterogenitas rasa sesuai pasar yang akan dituju. Bertolak dari hal tersebut kiranya kita dapat memahami bahwa globalisasi sangat berkaitan dan tidak terpisahkan dengan glokalisasi seperti dua sisi dalam satu keeping mata uang. 


\section{Daftar Pustaka}

Aida, Ridha. 2005. "Liberalisme dan Komunitarianisme: Konsep tentang Individu dan Komunitas". Demokrasi vol. IV No. 2 Th. 2005. hlm 95-106

Halwani, Hendra. 2005. Ekonomi Internasional dan Globalisasi Ekonomi. Bogor: Ghalia Indonesia

Held, D., McGrew, A., Goldblatt, D., \& Perraton, J. 1999. Global transformations, introduction. Cambridge: Polity Press

James, Paul. 2006. Globalism Nationalism Tribalism, Bringing Back In. London: Sage Publications

James, P., \& Steger, M. B. 2010. Globalisation and culture, Vol. 4. Ideologies of globalism. London: Sage Publications

Jati, W. R. (2013). Memahami globalisasi sebagai evolusi kapitalisme. Jurnal Global dan Strategis, 7(2), 241-258.

John, B., \& Steve, S. 2001. The Globalization of World Politics, an Introduction to International Relations. New York: Oxford University Press

Julianto, Arhando, P. (2017). Indofood: Ini Rahasia Mengapa Indomie Populer di Negara Lain. Melalui https://ekonomi.kompas.com/read/2017/06/08/062000926/indofood.ini. rahasia.mengapa.indomie.populer.di.negara.lain [04/04/2018]

Koran Sindo (2015). Indomie Dominasi di 100 Negara. Melalui https://nasional.sindonews.com/read/1003200/149/indomie-dominasidi-100-negara-1432094803 [04/04/2018]

Kotler, P., Keller, K., Lane., Koshy, A., Jha., M. 2009. Marketing management: A south Asian perspective. Delhi, Cennai: Pearson Education India

Levitt, T. 1983. "The Globalization of Markets". Harvard Business Review. hlm 220.

McDonald Annual Report (2016). Melalui http://corporate.mcdonalds.com/content/dam/gwscorp/investorrelations-content/annual-reports/2016\%20Annual\%20Report.pdf [04/04/2018]

Miracle, G.E., Taylor, C.R. and Chang, K.Y. 1992. Culture and advertising executions: a comparison of selected characteristics of Korean and US television commercials, International Marketing Review, Vol. 9 No. 4 , 
Morrice, D. 2000, "The liberal-communitarian debate in contemporary political philosophy and its significance for international relations". Review of International Studies, vol 26, no 2: 233-251

Ramadhana, Ahada. (2015). Mi instan Indonesia juga bikin lidah orang Arab dan Eropa ketagihan. Melalui https://www.brilio.net/news/mi-instanindonesia-juga-bikin-lidah-orang-arab-eropa-ketagihan-1506049.html [04/04/2018]

Robertson, Roland. 1992. Globalization: Social theory and global culture (Vol. 16). London: Sage

Robertson, Roland. 1995. "Glocalization: Time-Space and HomogeneityHeterogeneity". Dalam Global Modernities. Edited by Mike Featherstone, Scott Lash and Roland Robertson. hlm. 25-44. London: Sage

Shafi, S. I., \& Madhavaiah, C. 2014. "Impact of Promotional Activities on Brand Equity in Selected Apparel Brands: Evidence from India”. Asia-Pacific Marketing Review. 59

Steger, B. Manfred. 2003. Globalization: A Very Short Introduction. New York: Oxford University Press

Steger, B. Manfred. 2009. Globalization: A brief insight. New York: Sterling

Susanto, Heri. (2013). Cerita Indomie Sukses Menembus Pasar 80 Negara. Melalui https://katadata.co.id/opini/2013/09/23/cerita-indomie-suksesmenembus-pasar-80-negara [04/04/2018]

Wilk, Richard. (1995). Learning to Be Local in Belize: Global Systems of Common Difference, in Worlds Apart: Modernity Through the Prism of the Local, ed. Daniel Miller. London: Routledge, 110-31. 